\title{
Serum Oestradiol Pattern during Coasting is Different in Antagonist Cycles Compared with Long Agonist Cycles in In Vitro Fertilisation
}

\author{
Koray Elter ${ }^{1}$, Tijen Alev Özay², Elif Ergin² ${ }^{2}$ Murat Hakan Özörnek ${ }^{2}$ \\ ${ }^{1}$ Department of Obstetrics and Gynecology, Trakya University Faculty of Medicine, Edirne, Turkey \\ ${ }^{2}$ Eurofertil Reproductive Health Center, Istanbul, Turkey
}

\begin{abstract}
Background: GnRH agonists and antagonists have different mechanism of action, and therefore serum estradiol levels might differ during coasting in IVF. Aims: To compare the change in serum oestradiol levels after withholding the gonadotropins for coasting between long agonist and antagonist cycles. Study Design: Retrospective study.

Methods: Antagonist and long agonist cycles, in which coasting was performed, were analysed in this retrospective analysis. Antagonist cycles ( $\mathrm{n}=50$ ) were compared with long agonist cycles $(n=52)$ with respect to daily serum oestradiol levels following withholding of gonadotropins.

Results: The pattern of change in serum oestradiol was different between groups; it increased on the first day by $11.2 \%$ and decreased thereafter on the second and third days in the agonist group. However, it began to decrease from the first day in the antagonist group. Therefore, peak serum oestradiol levels were significantly higher in the agonist group than in the antagonist group (mean \pm standard deviation; $5798 \pm 1748 \mathrm{vs} 5104 \pm 1351 \mathrm{pg} / \mathrm{mL}$ ). The duration of coasting was shorter in the antagonist group compared with that in the agonist group (mean \pm standard deviation; $2.60 \pm 1.40$ vs $1.96 \pm 0.88$ days).

Conclusion: Serum oestradiol pattern during coasting is different in antagonist cycles compared with long agonist cycles in in vitro fertilisation.
\end{abstract}

Key Words: Ovarian Hyperstimulation Syndrome, Estradiol, coasting, GnRH antagonists

Received: 04.03.2013

Accepted: 19.09.2013

\section{Introduction}

Gonadotrophin-releasing hormone $(\mathrm{GnRH})$ agonists and antagonists have been widely used to prevent premature $\mathrm{LH}$ surge during ovarian stimulation for in vitro fertilisation (IVF) and embryo transfer (1-3). GnRH agonist suppresses gonadotrophin secretion through both pituitary desensitisation and $\mathrm{GnRH}$ receptor down-regulation, whereas $\mathrm{GnRH}$ antagonist competes with endogenous $\mathrm{GnRH}$ for receptor binding and therefore rapidly inhibits secretion of gonadotrophin (1). It has been suggested that the desensitisation by $\mathrm{GnRH}$ agonist has different effects on the intraovarian system than $\mathrm{GnRH}$ antagonist (4). Also, GnRH antagonist-treated women showed lower serum and follicular oestradiol concentrations on the day of human chorionic gonadotrophin (HCG) administration during IVF (5-8). This suggests a difference in ovarian oestradiol metabolism between the two protocols.

Coasting, i.e., withholding gonadotropin stimulation whilst continuing pituitary desensitisation for a variable number of days is the most popular strategy for the prevention of ovarian hyperstimulation syndrome (OHSS) during ovarian stimulation (9). The above-mentioned differences between agonists and antagonists suggest different effects on serum oestradiol levels during coasting. Therefore, in this retrospective analysis, we aimed to compare the change in serum oes- tradiol levels after withholding the gonadotropins for coasting between long agonist and antagonist cycles.

\section{Material and Methods}

Antagonist and long luteal agonist cycles, in which coasting was performed, were analysed in this retrospective analysis. Among 4220 cycles between 2001 and 2006, coasting was performed in 115 cycles. Coasting was performed for the indications of: [1] presence of $>20$ follicles, which were $>10 \mathrm{~mm}$ in diameter; and/or [2] presence of high ( $>4000 \mathrm{pg} / \mathrm{mL}$ ) serum oestradiol level. In all of these cycles, the follicular diameter for the smallest of the three leading follicles was $15 \mathrm{~mm}$. Serum oestradiol levels were determined daily or every other day during coasting until serum oestradiol levels decreased to $<4000 \mathrm{pg} / \mathrm{mL}$. Only women between the ages of 21 and 39 years $(n=102)$ were included in the analysis, to match the groups by age. Antagonist cycles $(n=50)$ were compared with long agonist cycles $(n=52)$ with respect to the duration of coasting and the serum oestradiol levels following withholding of gonadotropins. Pregnancy and implantation rates and the rate and severity of OHSS were also compared. The severity of OHSS was determined according to the Golan criteria (10). Cycle characteristics were compared by using the Student's t-test and chi-square test, where appropriate. Continu- 
Table 1. Age and cycle characteristics in the long agonist and antagonist groups (NS = not significant)

\begin{tabular}{|c|c|c|c|}
\hline & $\begin{array}{c}\text { Agonist cycles } \\
(n=52)\end{array}$ & $\begin{array}{l}\text { Antagonist cycles } \\
\qquad(\mathrm{n}=50)\end{array}$ & $\mathrm{p}$ \\
\hline Age (years) & $29.00 \pm 3.23$ & $30.58 \pm 4.85$ & NS \\
\hline \multicolumn{4}{|l|}{ Cause of infertility (n) } \\
\hline Male factor & 11 & 15 & \\
\hline Tubal factor & 4 & 2 & \\
\hline Ovulatoty dysfunction (PCOS) & 8 & 7 & \\
\hline Male and Famale (PCOS) factor & 11 & 9 & \\
\hline Male and Famale (othar than PCOS) factor & 3 & 4 & \\
\hline Endometriosis & 7 & 3 & \\
\hline Unexplained & 7 & 8 & \\
\hline Other & 1 & 2 & NS \\
\hline Duration of gonadotropin stimulation (days) & $9.21 \pm 1.81$ & $9.60 \pm 3.15$ & NS \\
\hline Total dose of recFSH (IU) & $1890 \pm 662$ & $2010 \pm 770$ & NS \\
\hline Serum $E_{2}$ level at the beginning of coasting $(\mathrm{pg} / \mathrm{mL}$ & L) $4521 \pm 698$ & $4588 \pm 658$ & NS \\
\hline Peak serum $\mathrm{E}_{2}$ level $(\mathrm{pg} / \mathrm{mL})$ & $5798 \pm 1748$ & $5104 \pm 1351$ & 0.03 \\
\hline Duration of coasting (days) & $2.60 \pm 1.40$ & $1.96 \pm 0.88$ & 0.007 \\
\hline Serum $E_{2}$ level on the day of $h C G(p g / m L)$ & $3211 \pm 942$ & $2966 \pm 972$ & NS \\
\hline Number of total oocytes & $15.25 \pm 7.61$ & $19.78 \pm 9.39$ & 0.009 \\
\hline Fertilization rate (\%) & 59.9 & 61.5 & NS \\
\hline Number of embryos transferred (n) & 3.4 & 3.5 & NS \\
\hline Pregnancy rate $(\% / E T)$ & 51.0 & 43.8 & NS \\
\hline Implantation rate (\%) & 21.5 & 19.2 & NS \\
\hline
\end{tabular}

Table 2. Daily serum oestradiol (E) levels ( $\mathrm{pg} / \mathrm{mL}$; mean \pm standard deviation) in antagonist and long agonist cycles

\begin{tabular}{|lccccccc|}
\hline & $\mathbf{n}$ & Day 1 & Day 2 & Day 3 & Day 4 & $\boldsymbol{\Delta}(\%)$ & $\mathbf{p}$ \\
\hline Agonist & 41 & $4533 \pm 742$ & $5048 \pm 1728$ & NA & NA & +11.2 & 0.036 \\
& 25 & NA & $5811 \pm 1596$ & $5169 \pm 2163$ & NA & -7.7 & 0.196 \\
& 17 & NA & NA & $6261 \pm 1336$ & $4628 \pm 2462$ & -25.0 & 0.144 \\
\hline Antogonist & 36 & $4629 \pm 706$ & $4342 \pm 1356$ & NA & NA & -4.8 & 0.233 \\
& 18 & NA & $5374 \pm 853$ & $3922 \pm 2145$ & NA & -29.3 & 0.003 \\
& 12 & NA & NA & $6004 \pm 1560$ & $4068 \pm 1715$ & -32.5 & 0.001 \\
\hline \multicolumn{5}{ll}{ Note: Each row indicates the results of two successive days only. ( $\Delta=$ Mean for [ELater day - EEarlier day] / EEarlier day; NA = not applicable) } \\
\hline
\end{tabular}

ous variables were compared using the former test, and rates were compared using the latter test. Each successive day was compared with each other by using Wilcoxon signed-rank test or paired t-test, where appropriate. The difference between the first and second days was compared using the paired $t$ test. The paired differences for the $2^{\text {nd }}$ day- $3^{\text {rd }}$ day pair and the $3^{\text {rd }}$ day- $4^{\text {th }}$ day pair were analysed using the Wilcoxon signed-rank test, due to the nonparametric nature of these data. Analysis of variance for repeated measures was not used since the number of subjects decreased with increasing number of successive days due to different durations of coasting. A further minor reason for analysing days separately was that serum levels had not been determined on weekends, i.e., daily, for every subject. The study was approved by the Institutional review board.

\section{Results}

Cycle characteristics and pregnancy rates are shown in Table 1. Age, total dose of gonadotropins, and serum oestradiol level at the beginning of coasting were comparable between groups (Table 1). Serum oestradiol levels had been determined both on the first day and on the second day only in 41 cycles in the agonist group $(n=52)$ and in 36 cycles in the antagonist group $(n=50)$. Serum oestradiol level had been determined the day after in the remaining cycles due to intervening weekend days. The number of available samples for the other pair of successive days is shown in Table 2. The pattern of serum oestradiol change was different between groups; it increased on the first day by $11.2 \%$ (mean \pm standard deviation [SD], from $4533 \pm 742 \mathrm{pg} / \mathrm{mL}$ to $5048 \pm 1728 \mathrm{pg} / \mathrm{mL}$ ) 
and decreased thereafter, by $7.7 \%$ and $25.0 \%$ on the second and third days, respectively, in the agonist group (Table 2). However, it began to decrease from the first day, by $4.8 \%$ (mean $\pm \mathrm{SD}$, from $4629 \pm 706 \mathrm{pg} / \mathrm{mL}$ to $4342 \pm 1356 \mathrm{pg} / \mathrm{mL}$ ) on the first day, and by $29.3 \%$ and $32.5 \%$ on the second and third days, respectively, in the antagonist group (Table 2). Therefore, peak serum oestradiol levels were significantly higher in the agonist group than in the antagonist group (Table 1). Serum oestradiol levels decreased to acceptable levels $(<4000$ $\mathrm{pg} / \mathrm{mL}$ ) in a shorter duration of time in the antagonist group compared with that in the agonist group (Table 1). A significantly higher number of oocytes were retrieved in the antagonist group than in the agonist group (Table 1). However, pregnancy and implantation rates were comparable between groups (Table 1).

Moderate and severe OHSS developed in seven and three women, respectively, in the agonist group. Corresponding values in the antagonist group were four and four. These rates were comparable between groups $(p>0.05)$

\section{Discussion}

Serum oestradiol level follows a different course during coasting in antagonist cycles compared with long agonist cycles. This causes a shorter duration of coasting in these cycles compared with long agonist cycles. This seems to be due to the initial decrease in serum oestradiol level during coasting in the antagonist group, in contrast to the initial increase in the agonist group. In the present study, age was comparable between groups. Previously, we analysed a larger group in a similar study design (11). However, age was significantly different between groups in that study. Although we believe that the differences we observed in that study were not due to the difference in age, we analysed age-matched groups in the present study, and found similar results. To our knowledge, the effects of agonists and antagonists on serum oestradiol levels during coasting have not been compared previously in an IVF programme.

Egbase et al. (12) have examined serum oestradiol and progesterone concentrations after stopping gonadotrophins in a long down-regulation protocol in 15 women for OHSS prevention. Similar to the results in the present study, the authors reported that serum oestradiol concentrations increased on the first day of coasting in 13 of the 15 women before falling in the following days (12). In addition, Sullivan et al. (13) observed an initial increase in serum oestradiol level on day one following withholding of gonadotropin stimulation during IVF in long agonist cycles. Gustofson et al. (14) analysed 12 women who were treated with a standard microdose lupron protocol and subsequently experienced ovarian hyperresponse with a markedly elevated oestradiol level inadequate for hCG injection. Lupron was discontinued and ganirelix was initiated. Gonadotropins had not been withheld. The authors observed that serum oestradiol levels decreased by $40 \%$ and $35 \%$ on the first and second days, respectively. In a similar study design, Gustofson et al. $(15,16)$ reported that women who had been switched from a $\mathrm{GnRH}$ agonist in a down-regulation protocol to a $\mathrm{GnRH}$ antagonist for the prevention of OHSS had a significant decrease in serum E2 levels within 24 hours of starting the antagonist, without coasting.

Our results suggest that the duration of coasting is shorter in antagonist cycles compared with agonist cycles. A shorter duration of coasting is also an advantage for the monitoring and cost of the cycle, i.e., a reduced number of visits and blood samples with a shorter duration of coasting. Although the effect of duration of coasting on IVF outcome, i.e., pregnancy and birth rates, is controversial, a significant impairment with a longer duration of coasting cannot be excluded with the available data (17-22). In the present study, the number of oocytes retrieved was significantly higher in the antagonist group compared with the agonist group; however, pregnancy rates were comparable between groups. An impairment in oocyte number with prolonged coasting was also previously reported (19, $20,22)$. Therefore, the shorter duration of coasting in antagonist cycles appears to be an advantage for both the burden and the success of IVF in women at serious risk of OHSS.

Major weaknesses of the present study are the retrospective design and that there were missing serum oestradiol values. Despite these missing values, the data for the first day of coasting appear sufficient to draw a reliable conclusion for the relevant day. The results in the present study need to be confirmed by a prospective study, which will allow daily serum oestradiol determinations.

In conclusion, the pattern of serum oestradiol during coasting is different in antagonist cycles compared with long agonist cycles in IVF. In antagonist cycles, the decline in serum oestradiol level following cessation of gonadotropin stimulation begins earlier than that in agonist cycles. This causes a shorter duration of coasting in antagonist cycles.

Ethics Committee Approval: Ethics committee approval was received from Trakya University Faculty of Medicine Medical Ethics Committee (2013).

\section{Informed Consent: N/A}

Peer-review: Externally peer-reviewed.

Author contributions: Concept - K.E., M.H.O.; Design - K.E., T.A.O., E.E., M.H.O.; Supervision - K.E., T.A.O., E.E., M.H.O.; Resource K.E., T.A.O., E.E., M.H.O. ; Materials - K.E., T.A.O., E.E., M.H.O.; Data Collection\&/or Processing - K.E., T.A.O., E.E., M.H.O.; Analysis\&/or Interpretation - K.E., T.A.O., E.E., M.H.O.; Literature Search - K.E., T.A.O., E.E., M.H.O.; Writing - K.E., T.A.O., E.E., M.H.O.; Critical Reviews - K.E., T.A.O., E.E., M.H.O.

Conflict of Interest: The authors declared no conflict of interest.

Financial Disclosure: The authors declared that this study received no financial support.

\section{References}

1. Elter K, Nelson LR. Use of third generation gonadotropin-releasing hormone antagonists in in vitro fertilization-embryo transfer:a review. Obstet Gynecol Surv 2001;56:576-88. [CrossRef]

2. Diedrich K, Diedrich C, Santos E, Bauer O, Zoll C, al-Hasani S, et al. Suppression of endogenous LH increase in ovarian stimulation with the $\mathrm{GnRH}$ antagonist Cetrorelix. Geburtshilfe Frauenheilkd 1994;54:237-40. [CrossRef]

3. Porter RN, Smith W, Craft IL, Abdulwahid NA, Jacobs HS. Induction of ovulation for in-vitro fertilisation using buserelin and gonadotropins. Lancet 1984;2:1284-5. [CrossRef] 
4. Lin $Y$, Kahn JA, Hillensjo $T$. Is there a difference in the function of granulosa-luteal cells in patients undergoing in-vitro fertilization either with gonadotrophin-releasing hormone agonist or gonadotrophin-releasing hormone antagonist? Hum Reprod 1999;14:885-8. [CrossRef]

5. Albano C, Felberbaum RE, Smitz J, Riethmuller-Winzen H, Engel J, Diedrich K, et al. Ovarian stimulation with HMG:results of a prospective randomized phase III European study comparing the luteinizing hormone-releasing hormone (LHRH)-antagonist cetrorelix and the LHRH-agonist buserelin. European Cetrorelix Study Group. Hum Reprod 2000;15:526-31. [CrossRef]

6. Olivennes F, Belaisch-Allart J, Emperaire JC, Dechaud H, Alvarez $S$, Moreau L, et al. Prospective, randomized, controlled study of in vitro fertilization-embryo transfer with a single dose of a luteinizing hormone-releasing hormone (LH-RH) antagonist (cetrorelix) or a depot formula of an $\mathrm{LH}-\mathrm{RH}$ agonist (triptorelin). Fertil Steril 2000;73:314-20. [CrossRef]

7. Roulier R, Chabert-Orsini V, Sitri MC, Barry B, Terriou P. Depot $\mathrm{GnRH}$ agonist versus the single dose $\mathrm{GnRH}$ antagonist regimen (cetrorelix, $3 \mathrm{mg}$ ) in patients undergoing assisted reproduction treatment. Reprod Biomed Online 2003;7:185-9. [CrossRef]

8. Garcia-Velasco JA, Isaza V, Vidal C, Landazabal A, Remohi J, Simon $C$, et al. Human ovarian steroid secretion in vivo:effects of $\mathrm{GnRH}$ agonist versus antagonist (cetrorelix). Hum Reprod 2001;16:2533-9. [CrossRef]

9. Abdallah R, Kligman I, Davis O, Rosenwaks Z. Withholding gonadotropins until human chorionic gonadotropin administration. Semin Reprod Med 2010;28:486-92. [CrossRef]

10. Golan A, Ron-el R, Herman A, Soffer Y, Weinraub Z, Caspi E. Ovarian hyperstimulation syndrome:an update review. Obstet Gynecol Surv 1989;44:430-40. [CrossRef]

11. Elter K, Ozay AT, Ergin E, Ozornek H. Serum estradiol pattern during coasting is different in antagonist cycles compared to long agonist cycles in in vitro fertilization. 14th World Congress on in Vitro Fertilization \& 3rd World Congress on in Vitro Maturation, September 15 - 19, 2007, Montreal, Canada. Abstract Book p. 130 [Abstract P-1258].

12. Egbase PE, Al Sharhan M, Berlingieri P, Grudzinskas JG. Serum oestradiol and progesterone concentrations during prolonged coasting in 15 women at risk of ovarian hyperstimulation syndrome following ovarian stimulation for assisted reproduction treatment. Hum Reprod 2000;15:2082-6. [CrossRef]
13. Sullivan MW, Stewart-Akers A, Krasnow JS, Berga SL, Zeleznik AJ. Ovarian responses in women to recombinant follicle-stimulating hormone and luteinizing hormone (LH): a role for $\mathrm{LH}$ in the final stages of follicular maturation. J Clin Endocrinol Metab 1999;84:228-32. [CrossRef]

14. Gustofson RL, Bush MR, Segars JH, Larsen FW. The novel use of ganirelix to rescue hyperresponding stimulation cycles from cancellation in patients treated with microdose lupron. 60th Annual Meeting of the ASRM. October $16-20,2004$, Philadelphia, Pennsylvania, USA. Fertil Steril 82, Suppl. 2, S32-S33.

15. Gustofson RL, Larsen FW, Bush MR, Segars JH. Treatment with gonadotropin-releasing hormone $(\mathrm{GnRH})$ antagonists in women suppressed with $\mathrm{GnRH}$ agonist may avoid cycle cancellation in patients at risk for ovarian hyperstimulation syndrome. Fertil Steril 2006;85:251-4. [CrossRef]

16. Gustofson RL, Segars JH, Larsen FW. Ganirelix acetate causes a rapid reduction in estradiol levels without adversely affecting oocyte maturation in women pretreated with leuprolide acetate who are at risk of ovarian hyperstimulation syndrome. Hum Reprod 2006;21:2830-7. [CrossRef]

17. The Practice Committee of the ASRM. Ovarian hyperstimulation syndrome. Fertil Steril 2008;90:S188-93. [CrossRef]

18. Abdalla $H$, Nicopoullos JD. The effect of duration of coasting and estradiol drop on the outcome of assisted reproduction: 13 years of experience in 1,068 coasted cycles to prevent ovarian hyperstimulation. Fertil Steril 2010;94:1757-63. [CrossRef]

19. Mansour R, Aboulghar M, Serour G, Amin Y, Abou-Setta AM. Criteria of a successful coasting protocol for the prevention of severe ovarian hyperstimulation syndrome. Hum Reprod 2005;20:3167-72. [CrossRef]

20. Ulug U, Bahceci M, Erden HF, Shalev E, Ben-Shlomo I. The significance of coasting duration during ovarian stimulation for conception in assisted fertilization cycles. Hum Reprod 2002;17:310-3. [CrossRef]

21. Isaza V, Garcia-Velasco JA, Aragones M, Remohi J, Simon C, Pellicer A. Oocyte and embryo quality after coasting:the experience from oocyte donation. Hum Reprod 2002;17:1777-82. [CrossRef]

22. Waldenstrom U, Kahn J, Marsk L, Nilsson S. High pregnancy rates and successful prevention of severe ovarian hyperstimulation syndrome by 'prolonged coasting' of very hyperstimulated patients:a multicentre study. Hum Reprod 1999;14:294-7. [CrossRef] 